Robak I.Yu.

\title{
VALUE OF KHARKIV NATIONAL MEDICAL UNIVERSITY IN FORMATION AND DEVELOPMENT OF UKRAINIAN HIGHER MEDICAL EDUCATION: HISTORICAL AND LEGAL ASPECT
}

Kharkiv National Medical University, Ukraine

Time flies and the 210-th anniversary of Kharkiv University foundation with its medical faculty passed into history. The community is always highly interested in the history of anniversaries because of the "milestones". Issues of their origin and roots are particularly interesting. The same situation occurred this time. In addition, Kharkiv University Consortium was created last year and our university became its part. Naturally, each member of the consortium tends to define its historical place in a single university space established in the city. In today's Kharkiv university atmosphere it is widely believed that V.N. Karazin Kharkiv National University is the only heir and successor to Imperial Kharkiv University. A modern Medical Faculty of V.N. Karazin Kharkiv National University is a successor of the correspondent Faculty of IKhU.

It is said that the existence of Kharkiv higher medical school can be counted from the foundation of Kharkiv University, but the history of KhNMU did not start from the Medical Faculty of Imperial Kharkiv University, because Medical Faculty of IKhU was not a legal entity. Its successor, Kharkiv Medical Academy, acquired the right of the legal entity only in 1920 and then transferred it to Kharkiv Medical Institute. Let us try to provide insight into this issue.

During the events of 1917 Imperial Kharkiv University somehow "lost" the word "imperial" in its name, although nobody changed its name officially. During 1918-1919 it hardly existed in the fires of revolutionary events. The Soviet authority was ultimately established in Kharkiv in December 1919. One of the primary steps of the Bolshevism dictatorship in the educational sector was the abolition of "bourgeois" university 
education. In 1920 the only Kharkiv University lost its legal status and was broken up

(Figure 1).

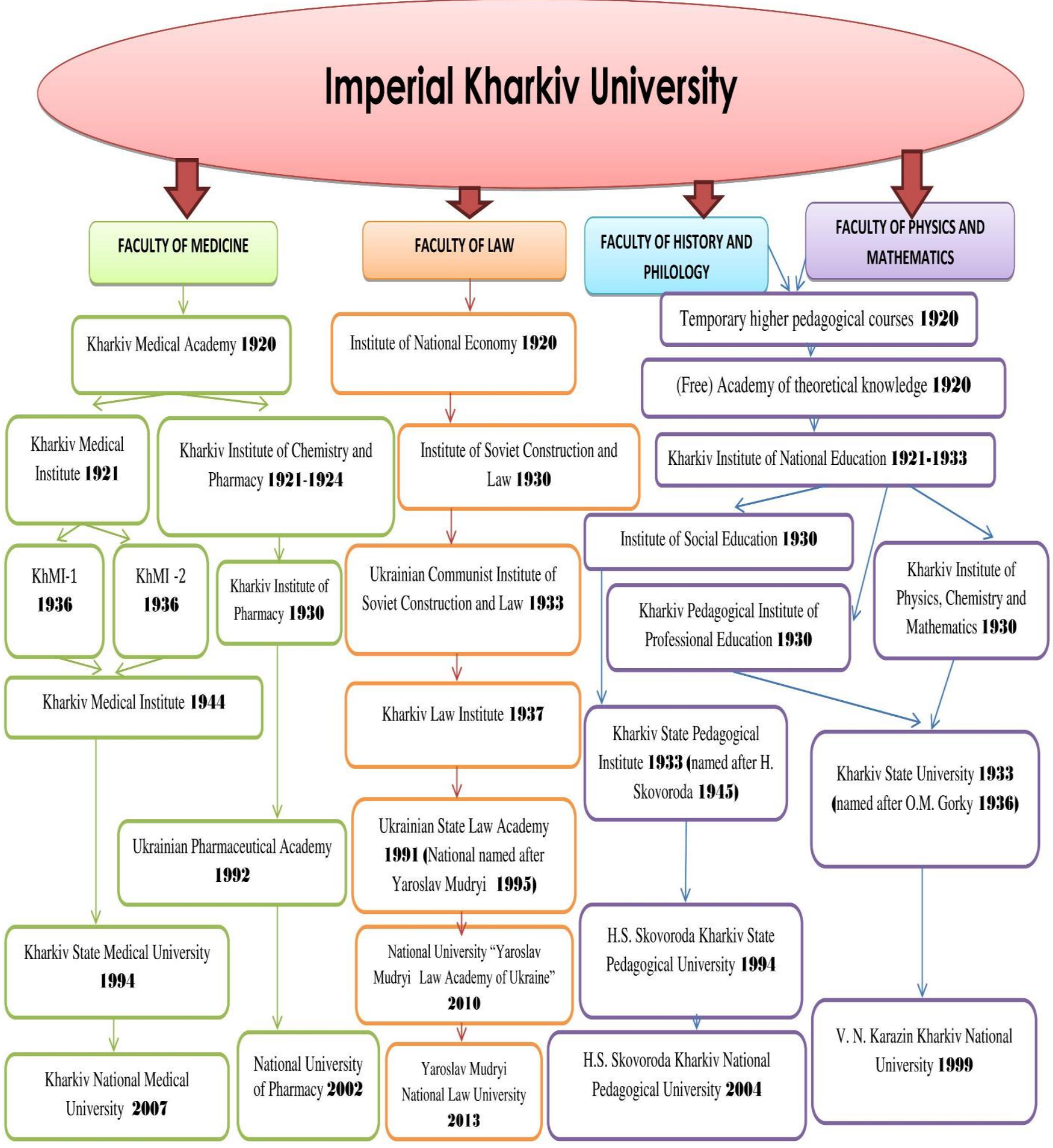

Figure 1. Flow diagram of Imperial Kharkiv University breaking up 
Its fragments, e.g. Kharkiv Medical Academy (Kharkiv Medical Institute since 1921), Institute of National Economy, Higher pedagogical courses (Academy of theoretical knowledge since July 1920) acquired the status of legal entities. Further transformation of University pieces continued for 13 years, when in 1933 Soviet Kharkiv State University was created by uniting Kharkiv Pedagogical Institute of Professional Education and Kharkiv Institute of Physics, Chemistry and Mathematics. It had no medical or legal faculty. That is, it was founded in the same way as our University was, i.e. it was founded on the ruins of pre-Soviet University. It did not happen in 1920, it was founded only after series of reforms and reorganizations of these "pieces", only in 1933 (Higher pedagogical courses, Academy of theoretical knowledge, Kharkiv Institute of National Education, Kharkiv Pedagogical Institute of Professional Education, Kharkiv Institute of Physics, Chemistry and Mathematics). It is so complicated that it is difficult to find the roots. So, why Kharkiv State University is considered to be the successor of IKhU, and at the same time, we are not considered to be the one? Is that because the main building on Universytetska Street, University Library and the monument to V.N. Karazin passes into its possession? But we also got all the facilities of the Medical Faculty of IKhU and it happened even earlier, in 1920. It may be the name itself - the "University". At that time Bolsheviks named all single-industry universities as institutes. We certainly do not wish to discredit the close relationship of Kharkiv modern classical university with its pre-Soviet predecessor but we have the same, if not bigger, reason to consider us as its successor.

Heredity and succession of the University institutions can be considered from two perspectives: legally and actually. In terms of the law we have to divide the terms "succession" and "legal succession". In law there is a term of "legal succession of states", which occurs in the event of termination of states and applies, particularly, to public property. So, in the event of termination of existence of the Russian state by the Bolsheviks in 1917, the succession of States did not occur. The Soviet authorities rejected it both in Russia (Russian Socialist Federative Soviet Republic) and in Ukraine (since 1919 Ukrainian Socialist Soviet Republic - a sovereign state before foundation of to the USSR). Kharkiv University was nationalized by the Bolsheviks, but it lost its 
succession of IKhU as an object of state ownership, like all its state institutions did throughout the sovereign Soviet republics. In 1920 it, as we have already mentioned, was divided into several universities. Faculty of Medicine was joined with the Women's Medical Institute KhMT to form Kharkiv Medical Academy. And (it is very important to recognize the succession) Medical Faculty fixed the assets (buildings, structures (including the faculty building at the corner of Kharytonenkovska and Sumska streets (now Pravdy ave.), e.g. Anatomy building, $4^{\text {th }}$ clinical hospital of "Clinical campus"), equipment, etc.) and the main teaching staff became part of the Academy.

After that we can talk not only about the succession, but also about the legal succession. Thus, on the basis of regulations of Ukrainian SSR, Kharkiv Medical Institute, created in 1921, became a legal successor of Kharkiv Medical Academy. In modern independent Ukraine Kharkiv Medical Institute became the legal successor of KhMI of Soviet times, according to the Law "On Succession of Ukraine" dated 12 September 1991, according to which Ukraine became a successor of all objects of state property, including our Institute due to the demise of the Soviet Union. Subsequently KhSMU became a legal successor of KhMI, and KhNMU became a successor of KhSMU.

This is the legal side of this issue.

Indeed, scientific schools are successive. According to this point of view, the university tradition has not been interrupted in some faculties of the present V.N. Karazin KhNU, Law University, University of Pharmacy and our university. Modern V.N. Karazin University has received the greatest scientific heritage, taking into account the number of inherited schools. So, we can recognize it as the main heir in schools succession. However, it did not inherit our research schools. The following scientific schools were established in the Faculty of Medicine of IKhU: anatomical, histological, biochemical, physiological, pathophysiological, surgical, obstetrical and gynaecological, paediatric, therapeutic, hygienic, psychiatric and microbiological. These schools reached their peak in the next period, the period of Kharkiv Medical Institute and Medical University, but not in the Faculty of Medicine of V.N. Karazin University. 
So, Kharkiv National Medical University is the actual direct heir and successor of the Faculty of Medicine of Imperial Kharkiv University from the very beginning of $\mathrm{IKhU}$; it is also a successor of Kharkiv Medical Academy, Kharkiv Medical (State Medical) Institute, Kharkiv State Medical University since 2007.

The relationship with Imperial Kharkiv University is declared by several modern Kharkiv universities. Let us see whether it is justified.

Yaroslav Mudryi National Law University (Figure 2).

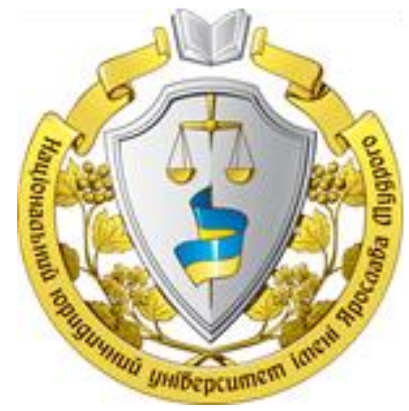

Figure 2. The logo of Yaroslav Mudryi National Law University

It is fully justifiable according to our point of view (Figure 3).

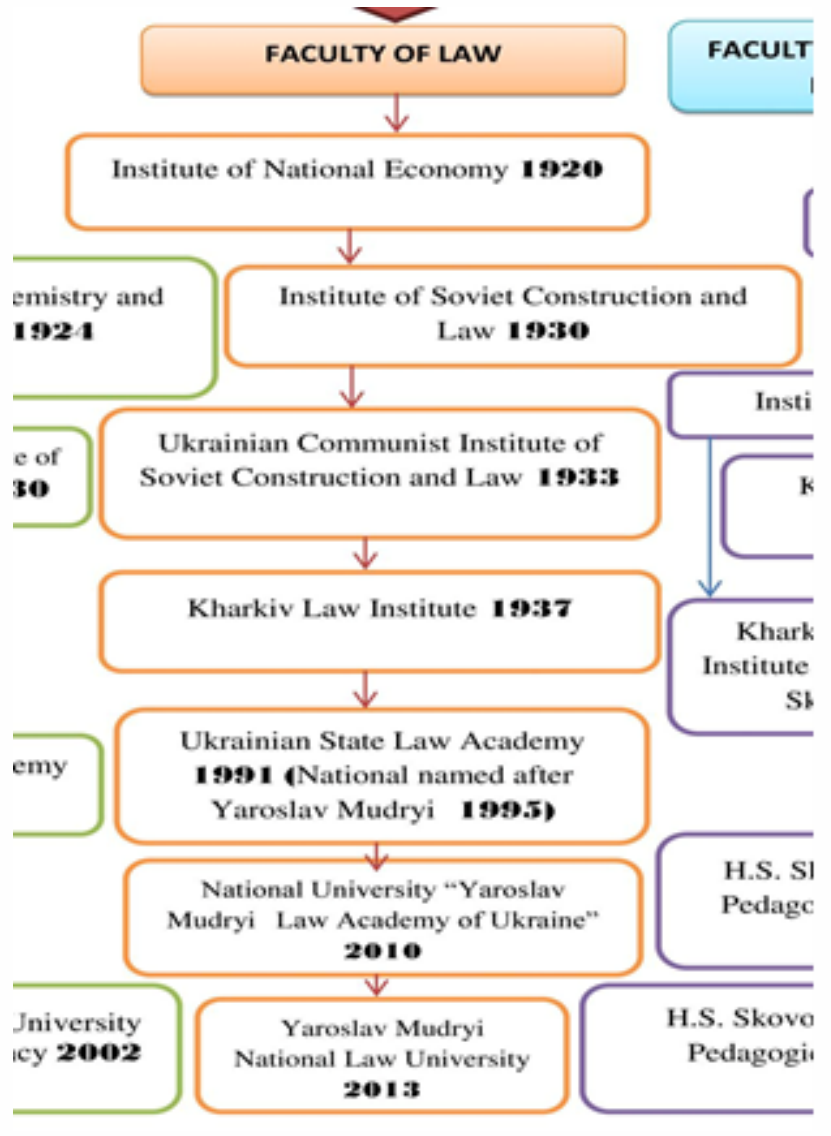


The Institute of National Economy was founded on the basis of the Faculty of Law of the University in 1920, having united with the Commercial Institute. Teachers came to the newly established university; Kharkiv university schools of law continued their development and did not stop it either in the Institute of Soviet Construction and Law established in 1930 or in Ukrainian Communist Institute of Soviet Construction and Law (1933-1937), or in Kharkiv Law Institute (1937-1991), or in Ukrainian State (National since 1995) Law Academy (1991-2010), with the present Yaroslav Mudryi National Law University which became its legal successor. Continuous relationship and development of the university tradition are evident.

The National University of Pharmacy (Figure 4).

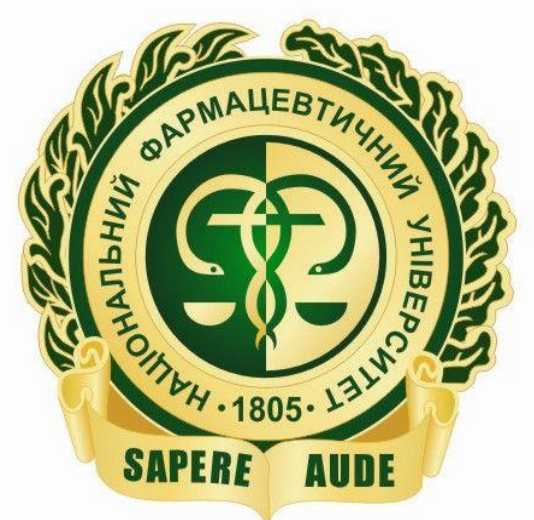

Figure 4. The logo of the National University of Pharmacy

The official website states that it "was founded in 1805 as a part of Kharkiv Imperial University". It is worth mentioning that during the years the Faculty of Medicine of this University included pharmaceutical laboratory; Department of Materia Medica, Pharmacy and Medical Literature; Department of Pharmacy and Pharmacognosy; Department of Pharmacology.

Pharmaceutical laboratory, founded in 1812, was its oldest structural unit. The logo includes 1805! And they came from the depths of the Faculty of Medicine (Fig. 5).

But it became an independent establishment, i.e. an institute, in 1921. Moreover, there was a college only, but not an institute, from 1924 to 1930 . Who are we if they are the successors of Imperial University? 


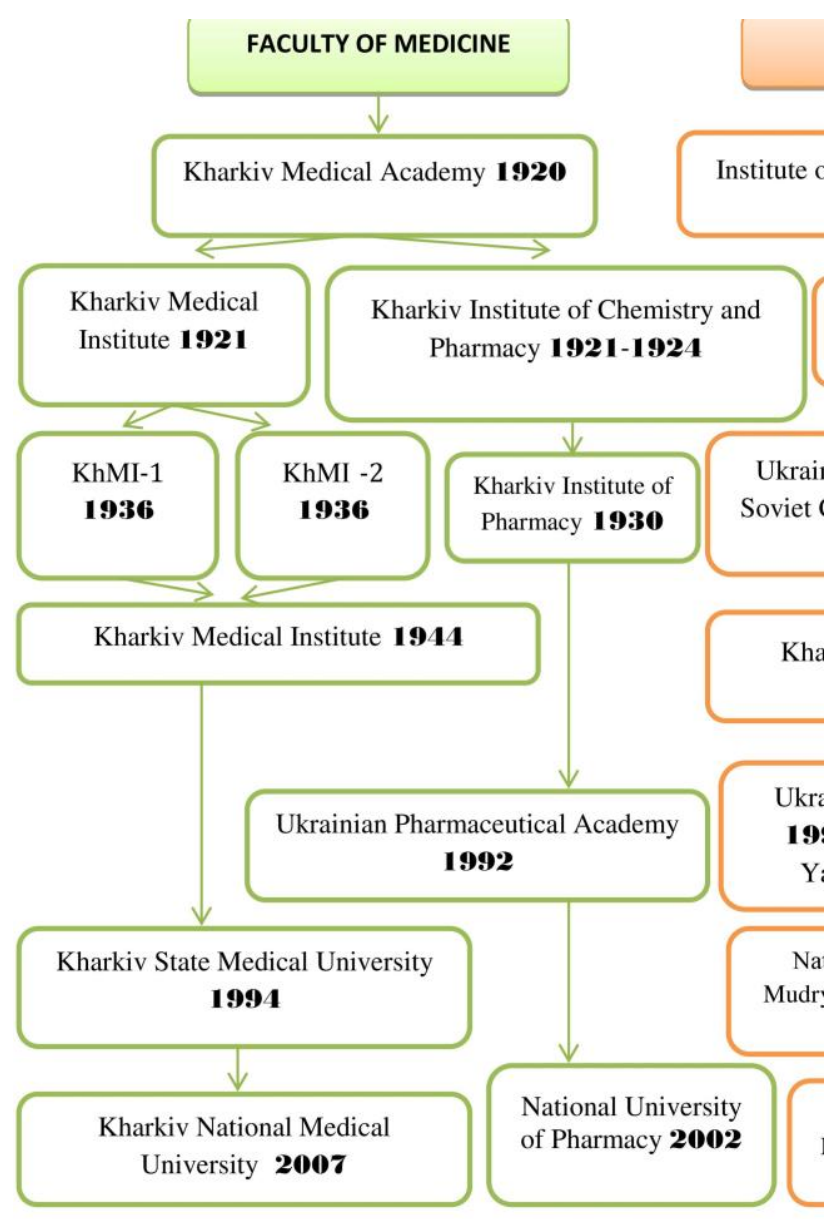

Figure 5. National University of Pharmacy foundation and development

Kharkiv State Zooveterinary Academy (Figure 6).

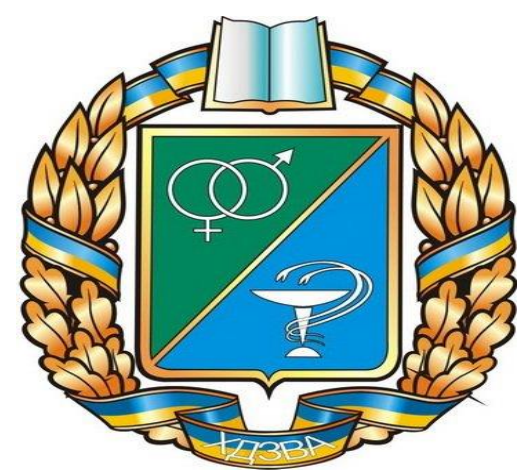

Figure 6. Kharkiv State Zooveterinary Academy foundation and development

The official website mentions the origins of their educational institution at the opening of the Department of cattle treatment within the Department of medical and health sciences of Kharkiv University in 1805 . However, they only say "origins", and the logo of the institution does not include that year. 
Kharkiv National Pedagogical University (Figure 7). They trace their history from 1804. Indeed, according to the first Charter of Kharkiv Imperial University in 1804 it assumed to be Teachers' or Pedagogical Institute.

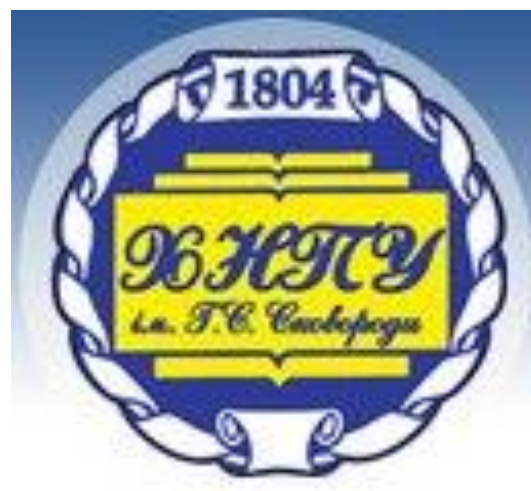

So, it was established. However, it happened later, in 1811. It existed until 1858, when it was replaced by pedagogical courses. By 1863 only three students finished those courses at Kharkiv University. The Charters of the Imperial University of 1863 and the last pre-Soviet of 1884 did not provide any pedagogical departments at the universities. That is, in 1863 university history of Kharkiv pedagogical education stopped. After that the Imperial

Figure 7. The logo of H.S. Skovoroda Kharkiv National Pedagogical University
University did not have a pedagogical institute, or pedagogical courses, or a relevant faculty or even a department.

That is why no further Kharkiv pedagogical scientific schools can be considered as successors of pre-Soviet University (Figure 8).

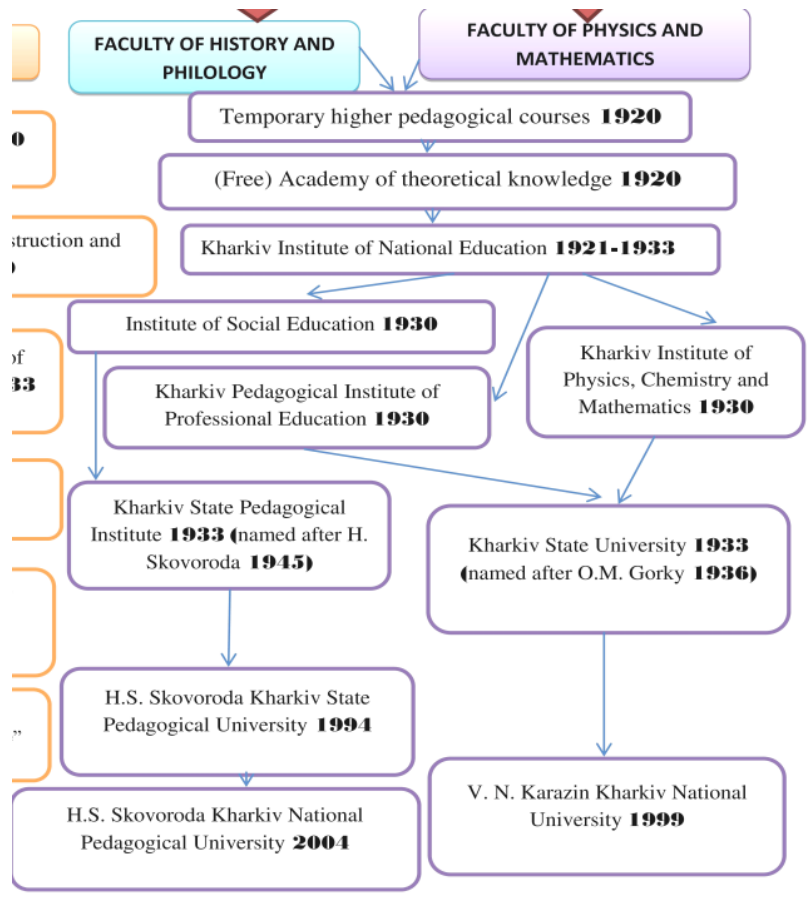

Figure 8. H.S. Skovoroda Kharkiv National Pedagogical University foundation and development 
The succession can be observed with Soviet Universities, namely Kharkiv Institute of National Education, Kharkiv Institute of Social Education, Kharkiv Pedagogical Institute. Kharkiv Pedagogical University is a legal successor of the last one.

Consequently, we consider that our University along with Yaroslav Mudryi National Law University are the direct successors of pre-Soviet Kharkiv

University, as these universities were founded directly on the basis of its departments in 1920. However, in Kharkiv university history we are older than the law school, as the Faculty of Medicine (according to the first Charter "Department or Faculty of Medical, of Healthcare Sciences") was founded along with the University but the Faculty of Law was established only in 1835, when the second Charter came into effect.

You have seen different dates on the logos. For clarity, we also demonstrate the logo of V.N. Karazin Kharkiv National University and the logo of our University (Figure 9). We can see the number "1804" on the logo of V.N. Karazin Kharkiv National University and the number " 1805 " on our logo.
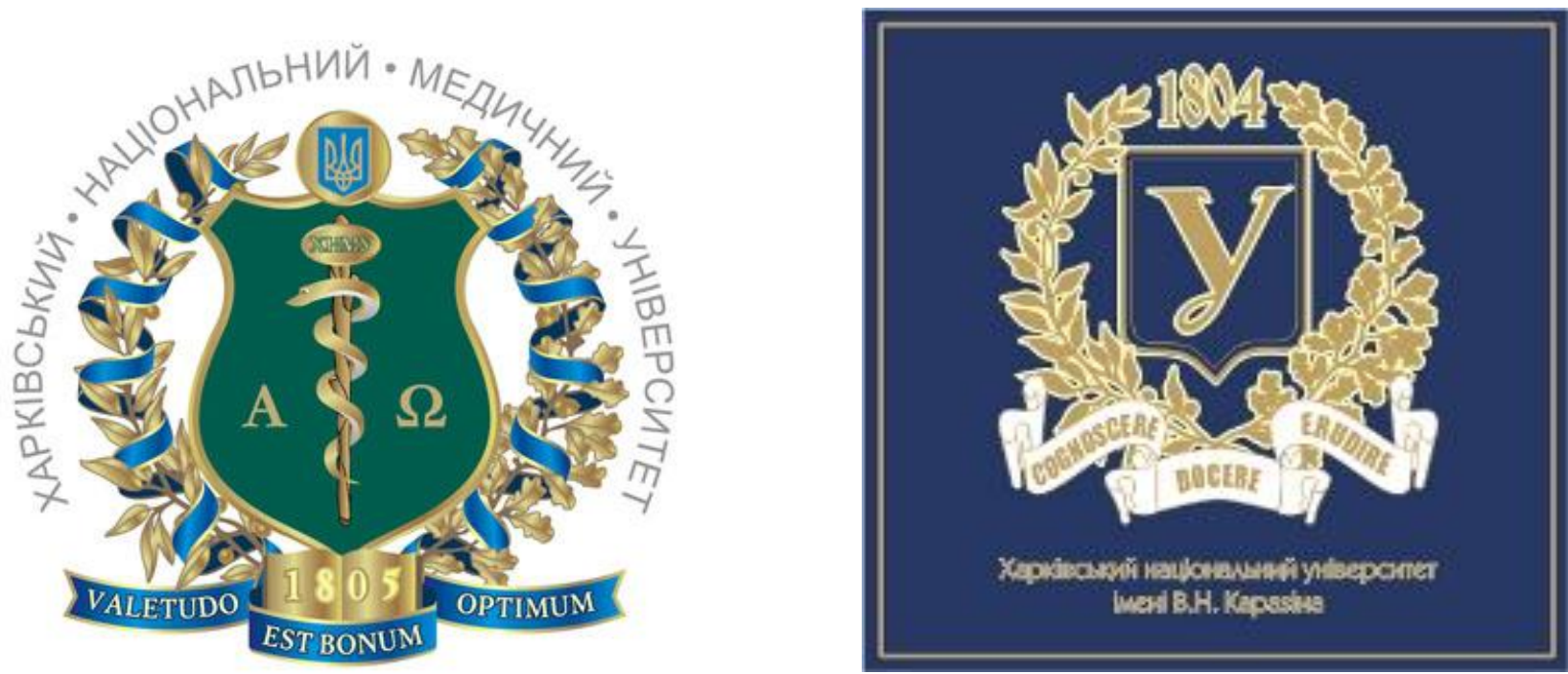

Figure 9. The logos of Kharkiv National Medical University and V. N. Karazin Kharkiv National University

So what is the actual, historically grounded date of the establishment of Imperial Kharkiv University?

In fact, this issue is simulated and is of scholastic nature only. 
Let us refer to the historical facts. On the $5^{\text {th }}\left(17^{\text {th }}\right.$ according to the Gregorian calendar) of November 1804 the Emperor of Russia Alexander I signed the constituent document on the establishment of Kharkiv University and approved its Charter. So is it logical to consider the year 1804 as the year of the establishment of Kharkiv University? Undoubtedly, it is. However, the University was not opened yet. It was officially opened on the $17^{\text {th }}$ ( $29^{\text {th }}$ according to the Gregorian calendar) of January 1805 (Figure 10).

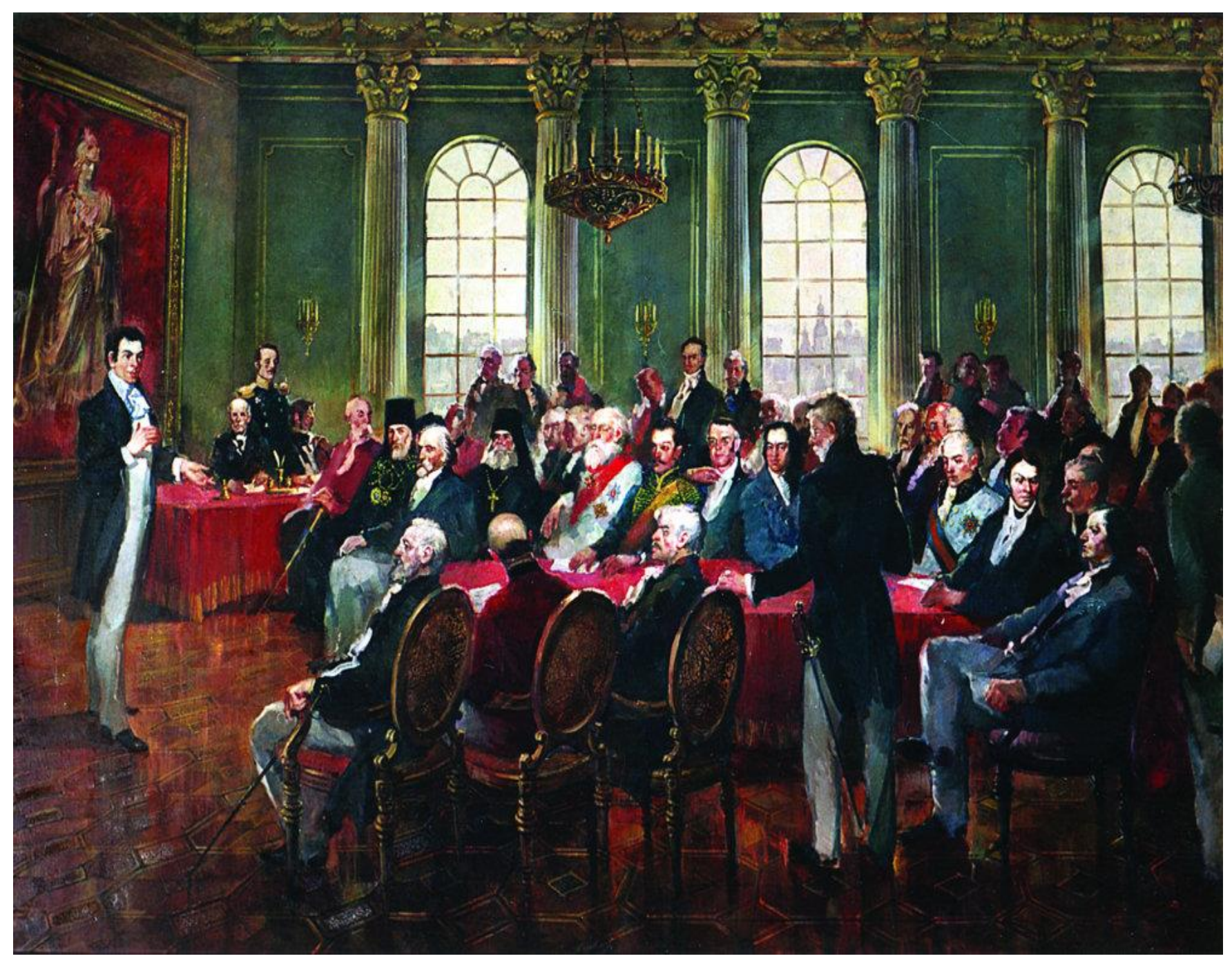

Figure 10. The first meeting of the Academic Board of Kharkiv Imperial University

On that day a solemn prayer, sacred procession, the first lectures and the first meeting of the Academic Board were held. Can we consider that the history of the University started at its official opening? We surely can.

People have argued and "crossed their swords" for over 150 years since the 50th anniversary of IKhU. 
There is a concept of "citation of authorities" in historical science. So, in the early twentieth century three recognized authorities, three coryphaeus of history: one of them, Mykola Fedorovych Sumtsov was a member of the Imperial St. Petersburg Academy of Sciences, and two others - Dmytro Ivanovych Bahaliy and Vladyslav Petrovych Buzeskul bacame academics in the nearest future and issued the monograph "Brief Essay on the history of Kharkiv University for the first hundred years of its existence (18051905)" (Figure 11).

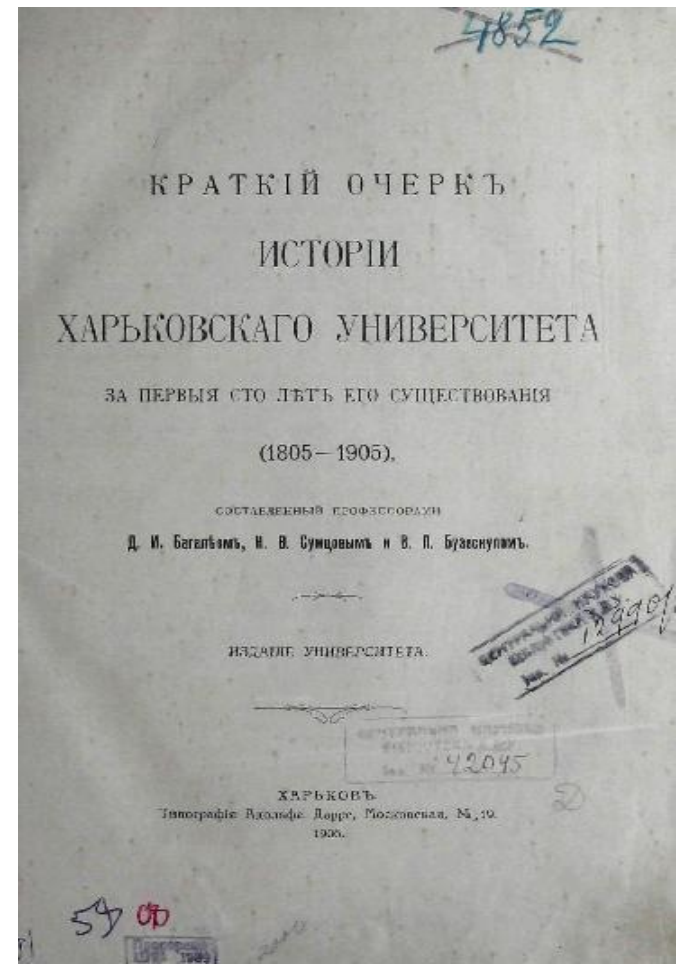

Figure 11. "Brief history of Kharkiv University for the first hundred years of its existence (1805-1905)"

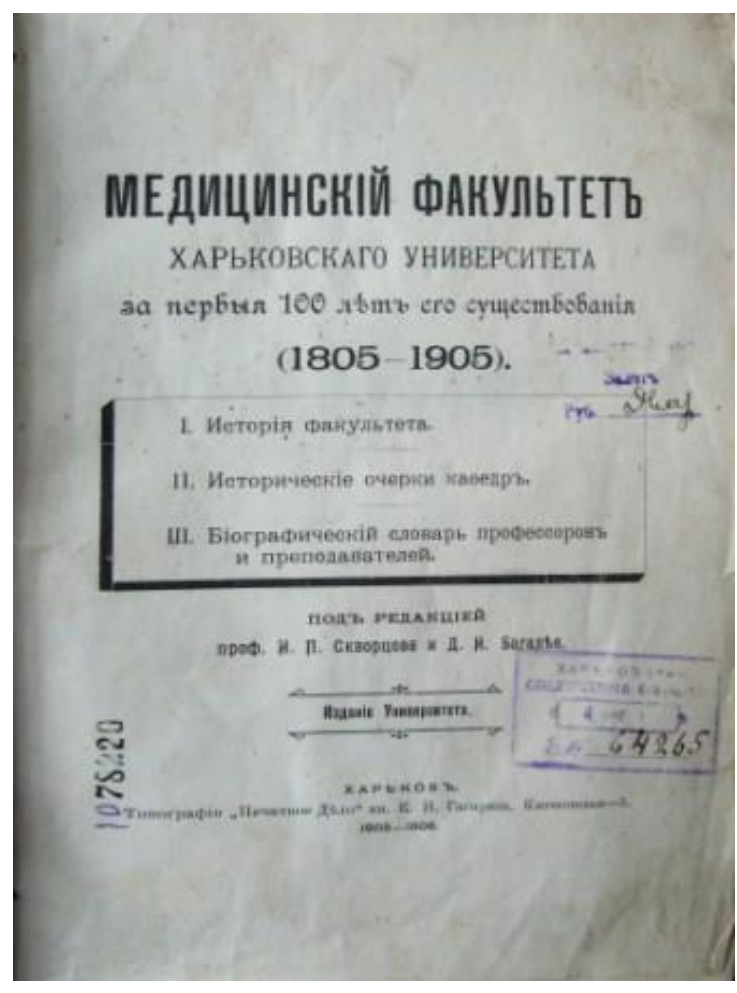

Figure 12. "Faculty of Medicine of Kharkiv University for the first hundred years of its existence (18051905)"

They clearly identified (see the title) the year of the establishment of the University, which is 1805 , in the monograph. Dmytro Ivanovych Bahaliy was the greatest authority on the history of Kharkiv, the future mayor of the city and the rector of Kharkiv University together with a famous professor hygienist Irynarkh Polikhroniyovych Skvortsov issued the book "Faculty of Medicine of Kharkiv University for the first hundred years of its existence (1805-1905)" in 1906 (Figure 12). 
Since that time Kharkiv University started to count its age, since 1805 . Nobody had any doubts, even Bolsheviks, who usually did not recognize the representatives of non-Marxist historical schools. Therefore, established in 1933 Kharkiv State University celebrated its 150th anniversary in 1955. It issued a

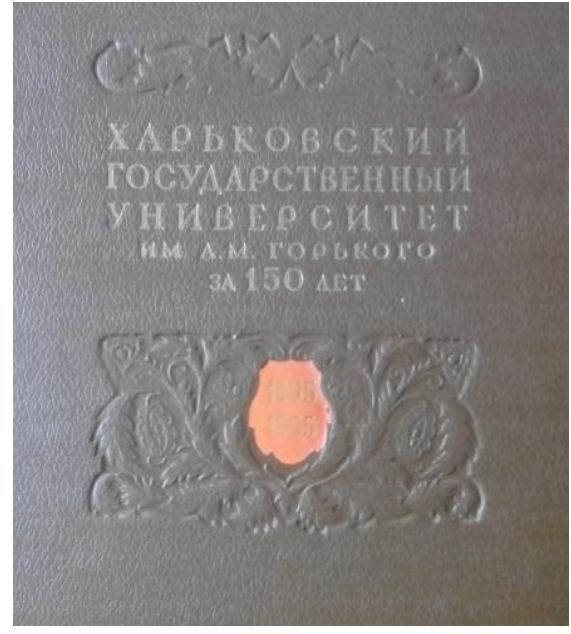

Figure 13. Anniversary edition for the 150th anniversary of the establishment of Kharkiv University confirming book (Figure 13).

Consequently, the $175^{\text {th }}$ anniversary was in January 1980. Then, 36 years on, Volodymyr Mykolayovych Lisovy and I were present on the ceremony. We received these books as a gift (Figure 14).

The year of the establishment of Kharkiv University is clearly identified on the cover in large numbers. Our Medical Institute has always been based on the year 1805 in its history. This is confirmed by the monograph "Brief history of Kharkiv Medical Institute", edited by the rector Borys Yakymovych Zadorozhniy in 1969 (Figure 15).

II C T 0 P $\mathrm{P}$ II II Х А Р Б КО В С KO Г O М ЕД И Ц Н С К О Г 0 И Н СТ ИТ Т Т А
ХАРЬКОВСКИЙ ГОСУДАРСТВЕННЫЙ УНИВЕРСИТЕТ

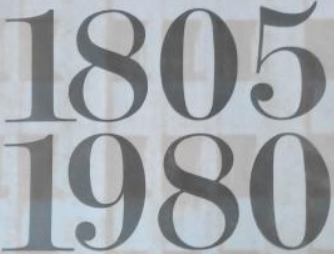
edition for the 175th anniversary of the establishment of Kharkiv University
Figure 14. Anniversary

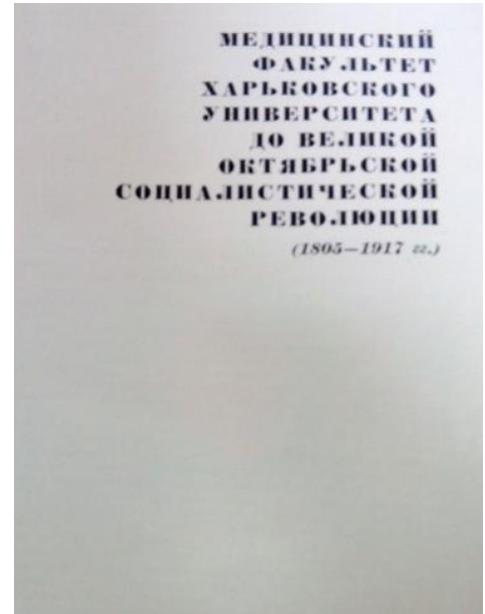

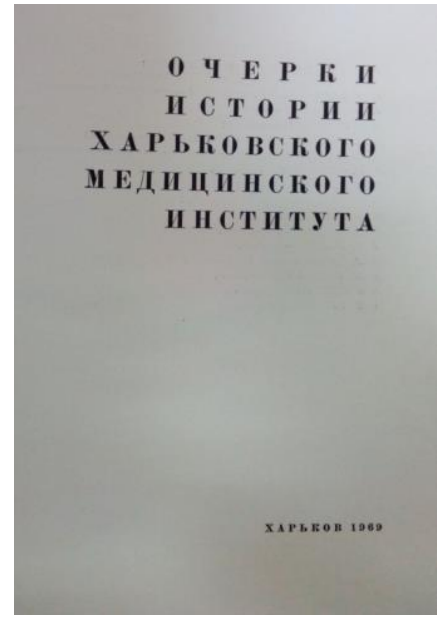

Figure 15. "Brief history of Kharkiv Medical Institute" 
So, preparing for the $200^{\text {th }}$ anniversary, our Scientific Board confirmed the logo and well-known publication of the anniversary monograph; and figure "1805" was everywhere (Figure 16).

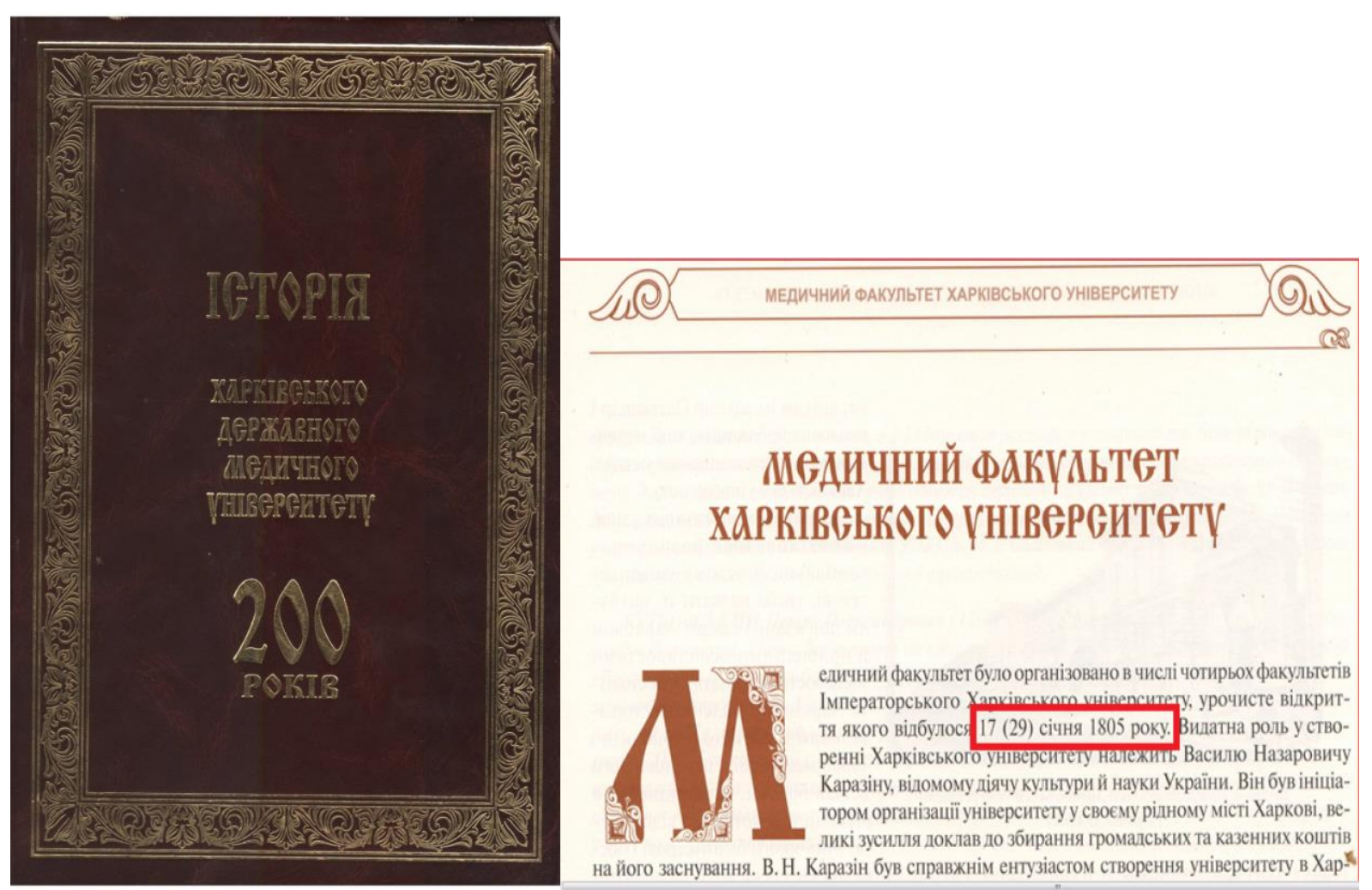

Figure 16. Anniversary monograph, issued for the 200th anniversary of KhSMU

In this respect we acted completely in accordance with the university tradition. It happened through no fault of ours that someone has decided to change it. Both the logo of V.N. Karazin Kharkiv National University and KhNPU (earlier) have included the figure "1804".

The fact that two terms "establishment" and "opening" are replaced by the term "creation". If we consider the "establishment", it is 1804. And 1805 is the year of opening. As for "creation", both points of view are possible. But for all institutions, which consider themselves as the successors, a single date shall be adopted. Mosaic is unacceptable because it causes the inequality of the successors and it recognizes inferiority of one compared to the others. This is a question of image and prestige. But we cannot get them round to this way of thinking. We cannot force them to change their logos, so does it mean we should change ours? 
Finally, we are going to consider the seniority of Ukrainian higher medical schools. It is worth mentioning that Saint Volodymyr University of Kiev with its Faculty of Medicine was established in 1834; and the seniority of Kharkiv higher medical school in Russian Ukraine has never caused any doubts. However, Danylo Halytsky Lviv National Medical University considers its history beginning in 1784, when the University was opened in Lviv according to the Decree of the Austrian Emperor Joseph II; it involved the Faculty of Medicine in accordance with its Charter (Figure 17).

They also claim that a lecture on medicine was held on the day of the University opening (but this fact should be checked). However, the Faculty of Medicine of Lviv University was officially opened only on 9 September 1894 and the first physicians graduated in 1900, while the Faculty of Medicine of Kharkiv University started to

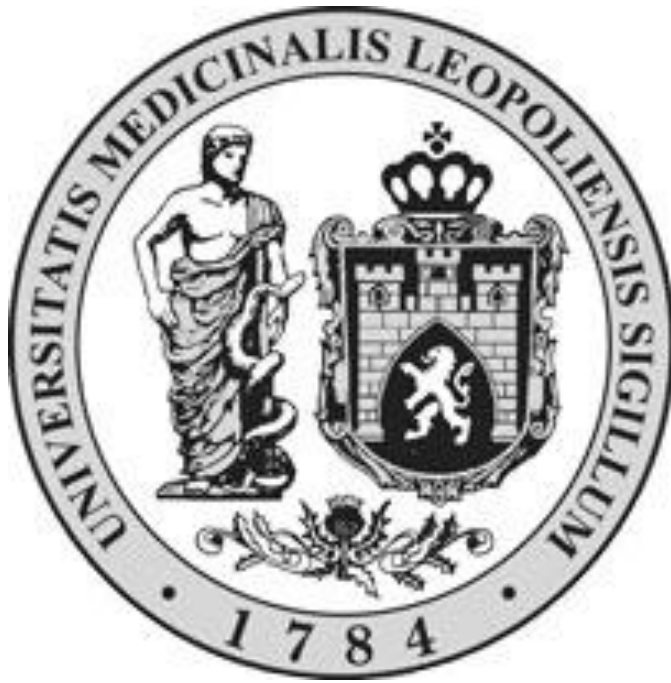

Figure 17. The logo of Danylo Halytsky Lviv National Medical University function immediately after the opening of the University in 1805 and the first physicians graduated in 1816. Thus, feel the difference, ladies and gentlemen! Consequently, historical facts prove that our Kharkiv higher medical school is the oldest in Ukraine.

To sum up, Imperial Kharkiv University and all scientific schools (medical, law, pharmaceutical, etc.) originated from it. In 1920 Bolsheviks broke it up. In 1921-1933 restructuring continued. Kharkiv State University appeared in 1933, and V.N. Karazin Kharkiv National University became its legal successor. Soviet KhSU had no Faculty of Medicine of Faculty of Law. Functioning nowadays Faculty of Medicine and Faculty of Law of V.N. Karazin Kharkiv National University cannot be considered as the successors of Faculty of Medicine and Faculty of Law of IKhU, because they were established in 80-90 years after its breaking up, although university tradition and development of scientific schools during their absence were not terminated. University flags were picked up and Kharkiv Medical and Law Institutes provided the further development of schools. Kharkiv National Medical University and Yaroslav Mudryi 
National Law University continue this affair. Their scientific and pedagogical achievements increased the heritage of pre-Soviet University. But modern "Karazin" Faculties of Medicine and Law began their history from "scratch", and they have to gain people's love and respect. We have already earned our reputation over more than 200years history, both in our country and around the world; and now we strengthen it for the benefit of Ukrainian nation! So Glory to our alma mater and glory to Ukraine!

Received: 15.12.2015

Accepted: 28.12.2015 